\title{
Forms of Government and Typology of Political Regimes in Ukrainian Socialist-Oriented Political Theory of Western Ukraine in the Interwar Period of the $20^{\text {th }}$ Century
}

\author{
Ustroje polityczne i typologia reżimów politycznych \\ w teorii zachodnioukraińskiej szkoły socjalistycznej \\ w okresie międzywojennym
}

\section{- Abstrakt •}

Przekonania teoretyków szkoły zachodnioukraińskiej, publikacje oraz deklaracje stanowisk partii o dążeniach socjalistycznych zostały zbadane dla celów analizy ustrojów i instytucjonalnych podstaw państwa. Zanalizowany został również wkład ukraińskich socjalistycznych myślicieli w zakresie problematyki związanej z klasyfikacją reżimów politycznych oraz zdefiniowaniem ich wyznaczników. W artykule przedstawiono wkład naukowy teoretyków ukraińskich socjalistycznych opinii politycznych w badanie form ustroju politycznego, zasady podziału władzy, mechanizmów gwarantujących zachowanie równowagi politycznej pomiędzy odmiennymi rodzajami władzy, instytucjami państwowo-politycznymi, parlamentem i rządem, problematykę praw i wolności osób, procesu wyborczego oraz przywódców lokalnych władz samorządowych. W artykule zaprezentowano priorytety polityczne naukowców i ideologów ukraińskiego zorganizowanego socjalizmu oraz ich teoretyczne konstrukcje procesu politycznego.

\section{- Abstract •}

Persuasion of theorists of Ukrainian political opinion of Western Ukraine, publications and position papers of socialistic aspiration parties for the purpose the analysis of forms and institutional bases of the state are investigated. The input of the Ukrainian thinkers-socialists in the range of problems of classification of the political regimes and determination of their signs are analysed. The scientific contribution of theorists of Ukrainian political opinion of socialistic aspiration out to research of forms state government, principle of distribution of power and system of inhibitions and counterbalances between its branches, state-political institutions of the country, parliament and government, problems of rights and freedoms of a person, electoral process, and local selfgovernment leaders are found out. Political priorities of scientists and ideologists of Ukrainian organized socialism are investigated, their constructions of process are exposed. 
Słowa kluczowe: państwo, socjalizm, poglądy polityczne, ustrój polityczny, podział władzy
Keywords: state, socialism, political opinion, political regime, distribution of power

\section{Introduction}

Research of domestic political thought and practices of political organization acquires an important value in our time not only in terms of actualization of political science inheritance of the Ukrainian thinkers, but, foremost, in terms of optimal use of ideological and theoretical works and practical experience of the past. In the time of development of state-political institutes in Ukraine, forms of state research issues have become especially important, in particular the scientific heritage of the Ukrainian political theoreticians' thoughts on the subject of the analysis of forms of government and typology of political regimes, whose value for modern political theory and practice of state-building is undoubted.

\section{Methodology}

Some aspects of the theoreticians' viewpoints of Ukrainian political thought of Western Ukraine socialist direction were investigated in Boris Kukhta's (Kukhta, 1993) and Tatiana Hodak's (Khodak, 2008) works. The programmatic documents of parties' socialist direction became the subject of a number of historical researches (Kuhutyak, 1993; Kul'chyts'kyy, 1999; Raykivs'kyy, 1995). However, political science component of the analysis of this problem, especially on the subject of the state remains largely unexplored.

The aim of this study is to clarify the issues and forms of government typology of political regimes and the process of Ukrainian state-building in Ukrainian political socialist oriented thought of Western Ukraine.

\section{Results and Discussion}

"The state is a juridically united people on some certain area with the constant independent authority" - the following definition of the state was proposed by Matviy Stakhiv (member of USRP), who is a theoretician of Ukrainian organized socialism, one of the brightest representatives of Ukrainian political socialist oriented thought of Western Ukraine. This formulation is similar to those definitions 
which were suggested by modern political science, in particular to the provisions of the juridical theory of the state's origin, considering it as a juridical form of organization and functioning of political authority. According to Stakhiv, the state is disclosed because of its basic characteristics such as a territory, population, and authority; thus "people are the most important foundation of the state" (Stakhiv, 1935). The meaning of the state as a category of political science is derived by the ideologist of socialism from its importance not only as a mechanical system of government establishment, as well as a combination of the government and the people, but also a system of institutions through which the authority is realized with the aim of ensuring security, order, and development of state's territory and its population. It is worth to pay attention to the fact that in a relationship between the state and citizens the priority is recognized according to the latter (the state is for man, not man for the state). In our opinion, protection of human rights and freedoms, security, and welfare are declared as the main duty of the state, which indicates the liberal origins and modern nature of Ukrainian socialism.

Through the prism of political science Ukrainian political socialist oriented thought of Western Ukraine also considers state forms, distinguishing two classic forms of state's government such as monarchy and republic. The legitimacy of the monarch's power is determined by "his own right to reign" (the source of power is the monarch), while the republic power "must be come from the people and is always elected" (the people are the source of power; Stakhiv, 1935). In the sequence of historical development three types of monarchies are distinguished: an elective monarchy, an absolute monarchy, and a constitutional monarchy. It was a clear realization that the forms of government do not exhaust the understanding of forms of the state.

The state's criteria of another typology have become "the different nature of authority" (political regime is a demonstration of this typology in the modern political science; Stakhiv, 1935). Based on this criterion Matthew Stakhiv distinguished such forms of government organization as democracy, aristocracy, theocracy, and dictatorship of the plutocracy. Democracy is a political regime in which "power comes only from the people's will"; when it is the aristocracy regime the state's authority which "is created by only one noble class"; theocracy involves identification of a terrestrial power with a religious power, state's power implementation of state is done by the "sacred class"; if it is plutocracy the power is held by the "class of the richest"; dictatorship involves concentrating all power in the hands of one person or group of people and total control over society through state bureaucracy can be "recognized clearly as dictatorship" or can pretend to be a different regime (Stakhiv, 1935). 
Essentially, regimes were classified as democratic and undemocratic. Moreover, dictatorship was seen as a kind of power, which is transitional either to democracy or to a harder (compared to dictatorship) regime of power (in modern political science it is a totalitarian regime). Based on the analysis of the communist and fascist ideologies and political regimes which were established in a number of countries in the interwar era (notably in Nazi Germany and Stalin's USSR), common features of communist and fascist regimes were described by the theoreticians of Ukrainian political socialist oriented thought of Western Ukraine.

"These are common features for these two movements: 1) Dictatorship is similarly adored and every possibility to destroy the very idea of democracy is used; 2) They equally despise the masses and are keen that people dutifully obey the dictator and his entourage who create a new gentry; 3) Holding their power, fascism and communism are similarly cruel and bloody systems of a terror killing millions people who have their own thought; 4) Fascists and communists equally do not acknowledge individual liberty, freedom of thought and speech, freedom of organization and science; 5) Both regimes equally aspire to state capitalism which harnesses all people under the command of the dictator's entourage" (Stakhiv, 1936). "The only difference between them is that the communists instead of the word 'nation', which has to hide fascist dictatorship, use the word 'proletariat', which has to mask commissar dictatorship that ultimately is no different from the Nazi” (Stakhiv, 1936).

In fact, signs of totalitarianism were determined before the explosion of World War II, long before the studies of this phenomenon were acknowledged in modern political science. This fact certainly is evidence of the maturity of the Ukrainian political thought in the interwar period and the high level of scientific analysis of its theoreticians. The ideologists of Ukrainian socialist oriented political thought of Western Ukraine uniquely positioned themselves as adherents of democracy. They have identified the following principles and signs of this regime: 1) Nation is the only source of power and the bearer of sovereignty ("Nation itself, all its members together are the bearers of power and independence"); 2) Personal and civil rights and freedoms (including freedom of political organization) are inviolable, in relations "person - state" the former occupies a privileged position; 3) Equality of all before the law; 4) The only way of forming government is "free election"; 5) Separation of powers into three branches: legislative, executive and judicial; 6) High level of political culture and general education of citizens ("without education proper information of the masses about state affairs is impossible"); 7) Free development of the press, without which "democratic system is impossible" (Stakhiv, 1935). 
It should be stated that most of the proclaimed principles are at the same time the legal states characteristics.

It was considered the problem of rights and freedoms in close connection with democracy as one of its basic characteristics. Personal rights and freedoms were allocated (privacy of citizens); civil rights and freedom: security of person, inviolability of the dwelling and property of citizens ("state authorities were not allowed to autocratically arrest citizens, were not allowed to do home or personal revisions, were not allowed to confiscate property"); special emphasis was placed on freedom of faith and belief: religious freedom, freedom of speech and printing; political freedom is considered no less important (considered as a condition and guarantee of compliance with all the other freedoms), to which the freedom of realization of mass actions and creating social and political organizations are attributed (Stakhiv, 1935).

The ideologists of Ukrainian political socialist oriented thought of Western Ukraine considered the differentiation of party as social consequence and it was viewed as a natural phenomenon of a democratic political process. Political parties had to reflect interests of different social groups, each wanting to influence the course of state policy. The necessity to observe social equality by socialists was especially emphasized when "the law does not make any difference regarding a person's position" (Stakhiv, 1935).

The distribution of power was one of the central problems of the state and its forms. Theoreticians of Ukrainian political socialist oriented thought of Western Ukraine proclaimed the "independence" of the three branches of government legislative, executive, and judicial as a necessary condition for democratic development, when "their mutual validity should be well-organized so that between those authorities was balance, namely, that one had no advantage over the second and could not enslave citizens" (Stakhiv, 1935). It is seen clearly as the principle of balance of power, i.e., the system of checks and balances that political science defines as a mandatory element of the democratic political process.

At the same time, Volodymyr Starosolskyi, a representative of Ukrainian political socialist oriented thought of Western Ukraine, criticized Montesquieu's theory about the separation of powers, thinking that this division is not possible, not only in the sense of balance and independence of powers, but also in terms of their functions and competencies. Thus, claimed the thinker, the term "executive power" was created by the political theory and accepted by practice is "false and does not correspond to the true sense of the state activity of which it is determined by" (Starosol's'kyy, 1950). On the one hand, the term is too wide because it covers also judicial power, which also executes laws and therefore is partly endowed with 
executive power; on the other hand, it is too narrow, because executive power also creates separate normative and legal acts, i.e. has practical elements of the legislature. Basically, Starosolskyi refused absolute statements about the division of powers into three branches, motivating it by the fact that none of the three powers are not only a carrier of power, it is believed that is exclusively accomplished by it. The thinker suggested using the term "administration" instead of "executive power".

People are the source of legislative power. M. Stakhiv claimed that "in direct democracy legislative power itself is created by the whole nation. In a representative democracy the nation makes the decision by voting about who should make laws on behalf of it". Thus, democracy has been divided into direct and representative. Executive power is called to execute the laws which were accepted by the parliament. Judicial power should operate on the basis of full independence and specialization. Matthew Stakhiv separately defines the public-political institution of the "head" (leader) of state and therefore "the home authority", which in monarchies is the hereditary monarch, and in republics is the elected president. Moreover, the head of state does not belong to any of the branches of government.

Based on analysis of the credential's balance in the power triangle "president - government - parliament", the system of government has been classified in a way similar to the division of republics into presidential, parliamentary and mixed that is proposed by the modern political science. "In some states, the president himself is the leader of the government and he is responsible for his policies ... In other only refers executive power, but is not responsible for its policy, because only ministers are responsible to the legislature... Finally, there is a mixed system where the president is unresponsible, but can execute some governmental acts himself" (Stakhiv, 1935).

B. Starosolskyi thoroughly analyzed competences in accordance with the principle of separation of powers. The thinker emphasizes the dependence of the competences on the form of government and form of state in general, as the division into the monarchy and the republic is not the only one possible. Thus, the powers of the supreme power (head of state) with a relatively large decrease in non-parliamentary states as the implementation of the principle of popular sovereignty state. The thinker's statement about greater compliance with the principles of parliamentary democracy form of government is therefore obvious.

In the context of the separation of powers, V. Starosolskyi assigned a specific role to the supreme power that is the institution of the president, depending on the form of government. "On a background of the division of authorities there was a necessity of establishment that is not overcome by a 'division' itself and it would retain connection between them and would give a guarantee that unity of the state 
will not be broken by divergence of three different 'authorities'. This is the supreme power" (Starosol's'kyy, 1950). The method of electing the head of state - directly by the people or the legislature depends on the government's form. Popularly elected head of state certainly has more a significant political and legal status. The President has a special privileged position in the civil and criminal law, which in modern constitutional law is defined as inviolability at the time of his authority.

Ukrainian socialist oriented political thought of Western Ukraine believed that an indicator of democracy and civic self-organization is the level of development of local self-government were "own affairs are discussed by concerned citizens though their trusted people, not though the state officials". The following types of local government were enumerated: social (level of settlement), district, and county.

Based on the principles of popular sovereignty, the only way of forming a government was to announce election. The election of the legislature in a representative democracy was seen as a procedure for transferring power from its carrier, i.e. people, to parliamentarians. Much attention was paid to the principles of organization and conduct of elections as a central element of the democratic political process. The right to vote in a democracy was universal, equal, secret, direct, and proportional (the latter concerned elections on party lists). The condition of preservation of democracy was proclaimed to be possible only through "free and unadulterated" elections with statutory punishment of all those that "would violate the purity of elections, in particular, complete freedom of election campaigning; 'impartial control of the legality of the election'; appropriate control of the voting process and counting of votes" (Stakhiv, 1935).

The theorists of Ukrainian socialist oriented political thought of Western Ukraine constructed a model of the future Ukrainian state according to the above described views on the institutional framework of the state. The organization of state power in Ukraine after independence must be a republican form of government and a democratic type of political regime. "Power in the people's labour state can not be monarchist, that is, where there is the royal court of the king with the king's supporters - gentry; this also can not be the power of dictatorial (fascist) that doesn't listen to anyone but only is advised by the military force; it must be the power of the republican, that is chosen by the people and responsible to the people" (Stakhiv, 1936).

The only possible way of forming a government and local governments in the Ukrainian state could only be elections. "Everything should be elected: Ambassadors to the Council of State, advisers to the regional councils, district councils and community councils. Elections must be secret, equal and direct (not through 
the voters). Judges, wardens, mayor and priests they all should be elected, not appointed. Only low officials may be called" (Stakhiv, 1935).

The distribution of power providing balance between the branches was proclaimed to be the condition of preservation of democracy and respect for the rights and freedoms of citizens of Ukraine. Particular attention was paid to the priority of human rights and freedoms. Freedom of speech, of social and political organizations, mass actions was seen as a means of public control over the state. "It is not enough to choose the power it is also needed to observe and monitor. In order to be free, criticism should be possible in newspapers, on assemblies and meetings, etc. There should be freedom (the will) to gather in communities and organizations, set up partnerships, go on strike. You can not arrest anyone without a court order. You can not force anyone to go to a foreign school, speak a foreign language, or move to another religion" (Stakhiv, 1935). Religious freedoms and the right of national-cultural autonomy were also considered very important, in particular the rights of national minorities regarding the development of the native language that confirmed the civility and tolerance of the Ukrainian socialist oriented political thought of Western Ukraine. The socialists considered it appropriate to eliminate such punishment as the death penalty and life imprisonment (note that today the elimination of the death penalty is a necessary condition of the Council of Europe participating countries).

Ukrainian organized socialism in Western Ukraine in the interwar period (socialist workers' party - the Ukrainian Socialist Radical Party and the Ukrainian Social Democratic Party) have kept the perspective on social justice and national equality, protection of rights, and also human and nation's freedoms. The moral dilemma in the politics of the socialists was decided in favor of the compatibility of politics and morality. USDP which occupied the left in the political spectrum focused more on social slogans. The ideologues of the party argued that stateless socialist people's national liberation is no less important than social. "Obtaining the national state is a major and immediate goal of the whole policy of an enslaved people, this is its historic to be or not to be" (Levyns'kyy, 1923).

\section{Conclusion}

Summarizing, we can state that theorists of Ukrainian socialist oriented political thought of Western Ukraine made a certain contribution to the development of political science, in particular, the perspective of the state and its forms. Classification of political regimes into democratic and undemocratic which is based on the 
analysis of common characteristics of fascist and communist ideologies and political regimes of the Nazi Germany and the Stalinist Soviet Union defined the characteristics of totalitarianism long before this phenomenon was recognized in contemporary political science.

It made scientific contributions to the study of forms of government, separation of powers and system of control and balances between its branches, state-political institutions of the President, Parliament and government, the problems of rights and freedoms, and the electoral process. The Ukrainian state was seen by socialists as socialist in content and national in form of a democratic Republic with broad powers of local governments, fair and transparent elections, political and ideological pluralism, and the priority of rights and freedoms. Certainly, all the above-mentioned testifies to the maturity of the Ukrainian political thought of the interwar period and a high level of scientific analysis of its theoreticians.

Different ideological directions of the Ukrainian political thought in Western Ukraine in the interwar period of the twentieth century require further investigation as to the subject entity and the classification of forms of the state and other political issues.

\section{References:}

Vdovychyn, I. (2010). Svoboda osoby v praviy ukrayins'kiy politychniy dumtsi (20-30 rr. XX st.). Ivano-Frankivs'k: Misto NV.

Starosol's'kyy, V. (1950). Politychne pravo: kurs lektsiy. Rehensburh-Novyy Ul'm: Ukrayins'kyy tekhnichno-hospodars' kyy instytut.

Stakhiv, M. (1935). Pro derzhavu. L'viv: Nakladom "Samoosvity".

Stakhiv, M. (1936). Demokratiya, sotsializm ta natsional'na sprava. L'viv: Nakladom "Hromads'koho holosu".

Stakhiv, M. (1936). Do dzherel nashoyi syly. L'viv: Nakladom "Hromads'koho holosu".

Stakhiv, M. (1935). Vlada narodu: rozvytok ideyi demokratiyi v novishykh chasakh. L'viv: Nakladom "Samoosvity".

Khodak, T. (2008). Derzhavno-pravova dumka v Zakhidniy Ukrayini (1919-1939 rr.): avtoref. dys. na zdobuttya nauk. stupenya kand. yuryd. nauk. Kyyiv: KNU im. T. Shevchenka.

Kuhutyak, M. (1993). Halychyna: storinky istoriyi. Narys suspil'no-politychnoho rukhu (XX st.- 1939). Ivano-Frankivs'k: B.v.

Kul'chyts'kyy, S. (1999). Ukrayina mizh dvoma viynamy (1921-1939 rr.). Kyyiv: Al'ternatyva. Kukhta, B. (1993). Z istoriyi ukrayins'koyi politychnoyi dumky pershoyi polovyny XX st. L'viv: LDU.

Levyns'kyy, V. (1923). Shcho take polityka. Praha-Berlin: Nova Ukrayina.

Raykivs'kyy, I. (1995). Ukrayins'ka sotsial-demokratychna partiya (1928-1939 rr.). IvanoFrankivs'k: B.v. 